\title{
Morphometrical, Histopathological, and Cytogenetical Ameliorating Effects of Green Tea Extract on Nicotine Toxicity of the Testis of Rats
}

\author{
Azza M Gawish ${ }^{\text {* }}$, Sherin Ramadan¹, Aziza M Hassan² and Aliaa M Issa \\ ${ }^{1}$ Department of Zoology, Faculty of Science, Cairo University, Dokki, Giza, Egypt \\ ${ }^{2}$ National Research Centre, Cell biology Department, Dokki, Giza, Egypt \\ ${ }^{3}$ National Organization for Drug control and Research, Dokki, Giza, Egypt
}

\begin{abstract}
This current study aimed at evaluating the toxic effect of nicotine and the possible protective role of green tea extract on some organs of Swiss albino mice by using histological, histomorphometerical and cytogenetical studies. Male Swiss albino mice were divided into four groups. The first group served as control and was injected intrapertoneally (i.p.) with

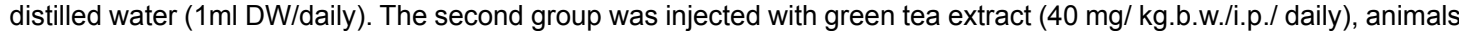
of the third group were injected with nicotine $(2.5 \mathrm{mg} / \mathrm{kg}$. b.w./i.p. daily) and those of the fourth group were injected with nicotine $(2.5 \mathrm{mg} / \mathrm{kg}$.b.w./i.p/daily) and green tea extract $(40 \mathrm{mg} / \mathrm{kg}$. b.w./i.p./daily). The experimental period was four successive weeks. Nicotine treatment induced histological changes in both the lung and testicular tissue as revealed by light microscope. It also induced histomorphological changes in the lung represent by significant decrease in elastic fibers and in the testicular tissue, a significant decrease in the number of Leydig cells. These changes were obtained by the computer image analyser. Combine administration of nicotine with green tea extract resulted in marked ameliorations of the testicular changes using histological and histomorphological observations. The combine administration of nicotine with green tea extract caused also an improvement in the ratio of PCEs/NCEs and a significant decrease in the increase of the MnPCEs numbers induced by nicotine treatment alone. In conclusions, the administration of green tea extract might suppress the cytotoxicity and mutagenic activity of nicotine. We suggest that green tea extract may be useful in combating tissue injury and genotocity caused by nicotine toxicity.
\end{abstract}

Keywords: Smoking; Nicotine; Antioxidant; Green tea extract; Histological; Histomorphometrical; Cytogenetical

\section{Introduction}

Cigarette smoking has been the most popular of taking nicotine since the beginning of the $20^{\text {th }}$ century. In which it has been identified injurious to human health. Each cigarette contains about 10 milligrams of nicotine [1]. Nicotine and its metabolites are also being investigated and researched for the treatment of a number of disorders, including Alzheimer's disease, attention deficit disorder and Parkinson's disease [2]. It induces oxidative stress both in vitro and in vivo and contributes with a major proportion to the net oxidative stress imposed by tobacco use, and at the same time, depletes antioxidant defense mechanisms [3]. The addictiveness of nicotine is being mediated by neuronal nicotinic acetylcholine receptors in the central nervous system [4] and is the cause of the continuing use of tobacco products. Gossian et al. [5] stated that cigarette smoking can affect the fertility of rats. The adverse effects of cigarette smoke on Leydig cell function in animals have been reported [6]. Kapawa et al. [7], showed that cigarette smoke - exposed results in secretor deficiency of Leydig cells and Sertiol cells leading to impaired epididymal sperm maturation process and diminished capacity of spermatozoa to penetrate oocytes. In addition, paternal cigarette smoke exposure affected the embryonic ability for implantation. Polyzos et al. [8], recorded also an increased risk for spontaneous abortions, and birth defects association with cigarette smoking. Genetic mutations in sperm were recorded by Yauk et al. [9] on exposed male mice to tobacco smoke. Yamamoto et al. [10] and Kim et al. [11] on their studies on cigarette smoking and nicotine (respectively) suggested a secretory dysfunction of the Leydig cells, and also a deficiency in sperm maturation and spermatogenesis. Reddy et al. [12] studied ascending concentrations of nicotine on testis and recorded a reduction in testis weight.
There is substantial evidence from human studies that cigarette smoke contains harmful mutagens and carcinogens; that may induce defective semen quality, nuclear DNA damage of spermatozoa, and compromise the chances of pregnancy [13]. However, Sergerie et al. [14] have found no association between smoking and sperm function or sperm nuclear DNA damage. Cigarette smokers have increased DNA strand breaks [15], DNA adducts [16], and chromosomal abnormalities $[17,18]$ in their sperm.

Doolittle et al. [19] concluded that neither nicotine nor its major metabolites cotinine, nicotine- $N$-oxide, and trans-30-hydroxycotinine caused genotoxic effects with or without metabolic activation. In contrast, other groups of researchers found a modest increase in sister chromatid exchange in Chinese hamster ovary cells [20], and in bone-marrow cells of mice with chromosomal aberration [21]. Other studies reported negative results in sister chromatid exchanges, chromosomal aberrations and micronucleated bone marrow cells of Sprague-Dawley rats nose exposed to the mainstream smoke generated by either traditional cigarettes or cigarettes which heat but do not burn tobacco [22]. Many references reported that nicotine has deleterious toxic effects through increased production of free radicals and reactive oxygen species (ROS) $[23,24]$.

*Corresponding author: Azza M Gawish, Department of Zoology, Faculty of Science, Cairo University, Dokki, Giza, Egypt, E-mail: azzagawish@ymail.com

Received October 05, 2010; Accepted November 22, 2010; Published Novembe 24,2010

Citation: Gawish AM, Ramadan S, Hassan AM, Issa AM (2010) Morphometrical, Histopathological, and Cytogenetical Ameliorating Effects of Green Tea Extract on Nicotine Toxicity of the Testis of Rats. J Cytol Histol 1:105. doi:10.4172/21577099.1000105

Copyright: (c) 2010 Gawish AM, et al. This is an open-access article distributed under the terms of the Creative Commons Attribution License, which permits unrestricted use, distribution, and reproduction in any medium, provided the original author and source are credited. 
Citation: Gawish AM, Ramadan S, Hassan AM, Issa AM (2010) Morphometrical, Histopathological, and Cytogenetical Ameliorating Effects of Green Tea Extract on Nicotine Toxicity of the Testis of Rats. J Cytol Histol 1:105. doi:10.4172/2157-7099.1000105

Page 2 of 7

Natural antioxidants with free radical-scavenging activity such as polyphenols from green tea extracts have received much attention as potential, non-toxic, treatments for oxidative-stressrelated pathological conditions. Green tea has also many biological functions include antioxidant, anticarcinogenic, anti-inflammatory, antimicrobial properties, antimutagenic, lowering plasma cholesterol and triglycerol levels, reducing blood pressure and platelet aggregation in human, animal, and in vitro studies [25].

The antioxidant properties, reactive oxygen species scavenging, and cell function modulation of flavonoids could account for the large part of pharmacological activity of green tea [26].

\section{Material and Methods}

\section{Experimental animals}

Eighty Male Swiss albino mice aged 9 - 12 weeks and weighing 25 -30 gm were used in this study. Nicotine was purchased in the form of colorless liquid in glass bottle at $100 \%$ concentration from faculty of Pharmacy, Cairo University, Egypt. The mean $\mathrm{LD}_{50}$ for intraperitoneal administration of nicotine to 8-week-old mice ( $29.6 \mathrm{~g})$ was reported as $12.5 \mathrm{mg} / \mathrm{kg}$.

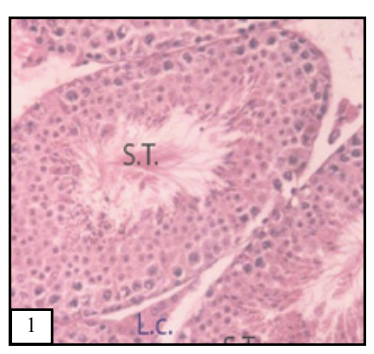

Figure 1: Micrograph of testis section of mice in control group showing normal architecture of somniferous tubules (S.T.) A typical appearance of mice seminiferous tubules with different cellular association. The tubules had normal progression cells and Leydig cells have normal disruption (L.C.) (H\&E., 200X).

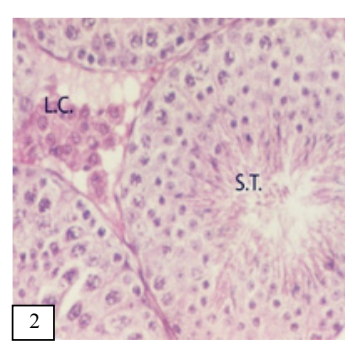

Figure 2: Micrograph of testis section treated with nicotine for a week showing complete spermatogenesis (S.T.) and nearly normal testis structure with lower decreased in population of Leydig cells (L.C.). (H\&E., 400X).

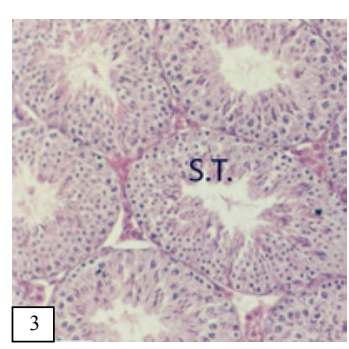

Figure 3: Micrograph of testis section treated with nicotine for three weeks showing apyknosis among spermatogenic cells especially necrosis in 1 ry $\& 2^{\text {nd }}$ spermatocytes (thin arrow). (H\&E., 400X).
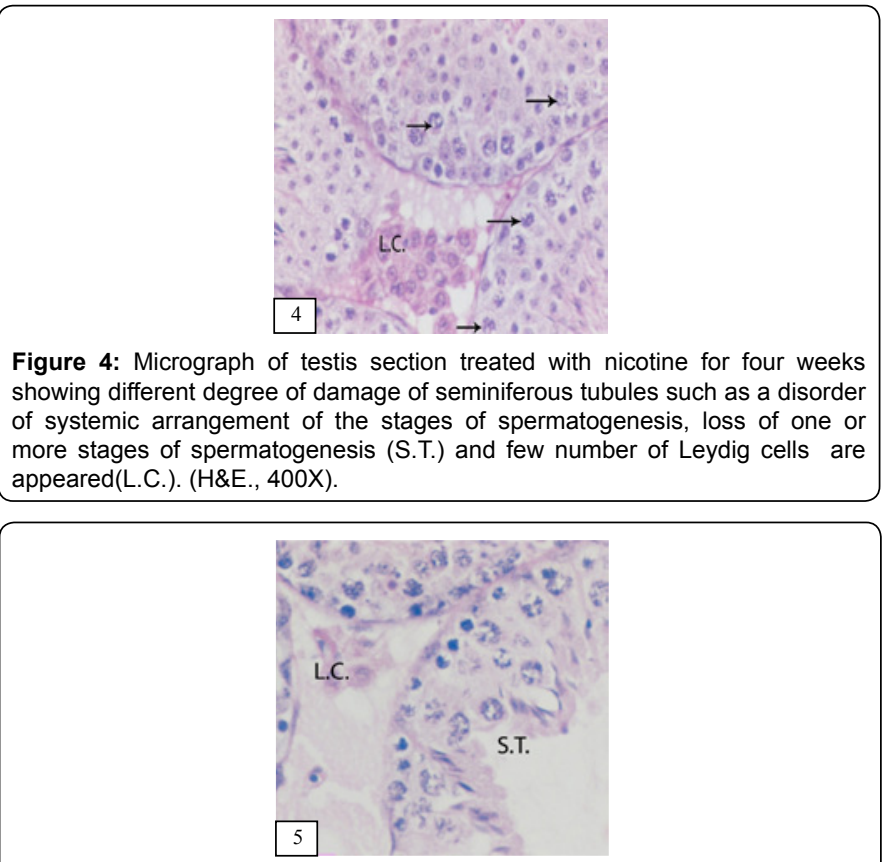

Figure 5: Micrograph of testis section treated with green tea concomitantly with nicotine for a week showing almost normal appearance of seminiferous tubules (S.T.) with normal spermatogenic cells and arrangement Leydig cells are more increased, (H\&E., 200X).

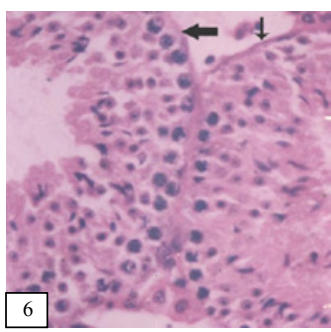

Figure 6: Micrograph of testis section treated with green tea concomitantly with nicotine for three weeks showing most of somniferous tubules had nearly normal structure (thick arrow.) and few of them had arrest (thin arrow.). (H\&E, 400X)

Green tea extract was purchased in form of tablets, each contained 200mg of green tea extract; it obtained from Techno-mad Groups Company, Egypt. Each tablet was dissolved in distal water and solution was injected intraperitoneal to experimental animals at dose level of $(40 \mathrm{mg} / \mathrm{k} . g . b . w$.$) according to [27]. For histology$ examination, the animal was cervical dislocation, Five micron thick paraffin sections were prepared, mounted on clean slides and stained with Ehrlich's haematoxylin-eosin [28]. The histomorphometrical analysis was obtained as the number of Leydig cells in testis, they were stained by Ehrlich's haematoxylin-eosin and examined by an objective lens of magnification X40. The micronucleus assay has been widely used to demonstration genotoxicity, both in vivo and in vitro [29].

Polychromatic erythrocytes and normochromatic erythrocytes were two types of erythrocytes could be distinguished in mouse bone marrow on the basis of their staining characteristics with MayGrÜnwald-Giemsa stain [30].

The animals were divided randomly into 4-groups of each group have 20 animals:

Control group: The animals were injected intraperitoneal with distilled water $(0.1 \mathrm{ml} / 10 \mathrm{gm}$.b.w.) daily for four weeks. 
Green tea extract treated group: The animals were daily intraperitoneal injected with green tea extract $(40 \mathrm{mg} / \mathrm{kg}$ body weight / day) for four weeks.

Nicotine treated group: The animals were daily intraperitoneal injected with nicotine $(2.5 \mathrm{mg} / \mathrm{kg} /$ day) for four weeks.

Nicotine green tea extract treated group: The animals were daily intraperitoneal injected with nicotine $(2.5 \mathrm{mg} / \mathrm{kg} / \mathrm{day})$ concomitantly with green tea extract ( $40 \mathrm{mg} / \mathrm{kg}$ body weight/day) for four weeks.

Statistical analysis: Statistical analyses were carried out using analysis of variance (One Way ANOVA) and Duncan's Test to determined difference between group means and stander errors. The values are mean \pm S.E. for five samples for each week. $P$-values $\geq 0.05$ were considered as significant, while $P$-values $\geq 0.001$ were considered as highly significant.

\section{Results}

The testis is the primary male sex organ and is also, an important endocrine gland. Sections in testis of control group revealed that seminiferous tubule; each has a definite basement membrane and a lumen which may contain a few spermatozoa (Figure 1 and Figure 2). Macroscopical examination of testis sections in male Swiss albino mice treated with green tea extract alone for one, two, three and four weeks respectively revealed normal testicular architecture with complete normal spermatogenic layers and well developed sperm. Interstial Leydig cells showed no structural abnormalities (Figure 3). Histological examination of testis sections in male Swiss albino mice treated with nicotine for one, two, three and four weeks respectively, revealed variable degrees of alteration according to the time of treatment and compared to control.

Marked reduction of sperm in some seminiferous tubules, in addition to, the appearance of few scattered pyknotic nuclei in the basal cell layers. Interstial Leydig cells showed also a mild reduction (Figure 4). Other seminiferous tubules showed areas of cystic degenerative changes accompanied with exfoliated spermatogenic

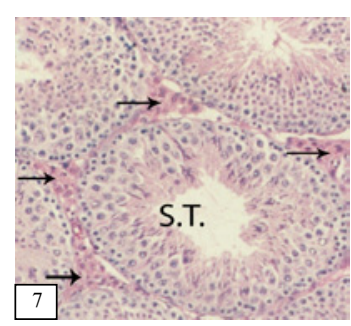

Figure 7: Micrograph of testis section treated with green tea concomitantly with nicotine for four weeks showing a little change in architecture of somniferous tubules with normal and order spermatogenesis (S.T.). (H\&E, 400X).

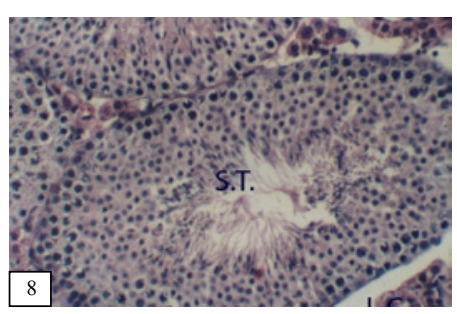

Figure 8: Micrograph of testis section treated with green tea showing a normal testis structure, complete spermatogenesis (S.T.) and normal appearance of Leydig cells (arrow) H \&E, 400 X).
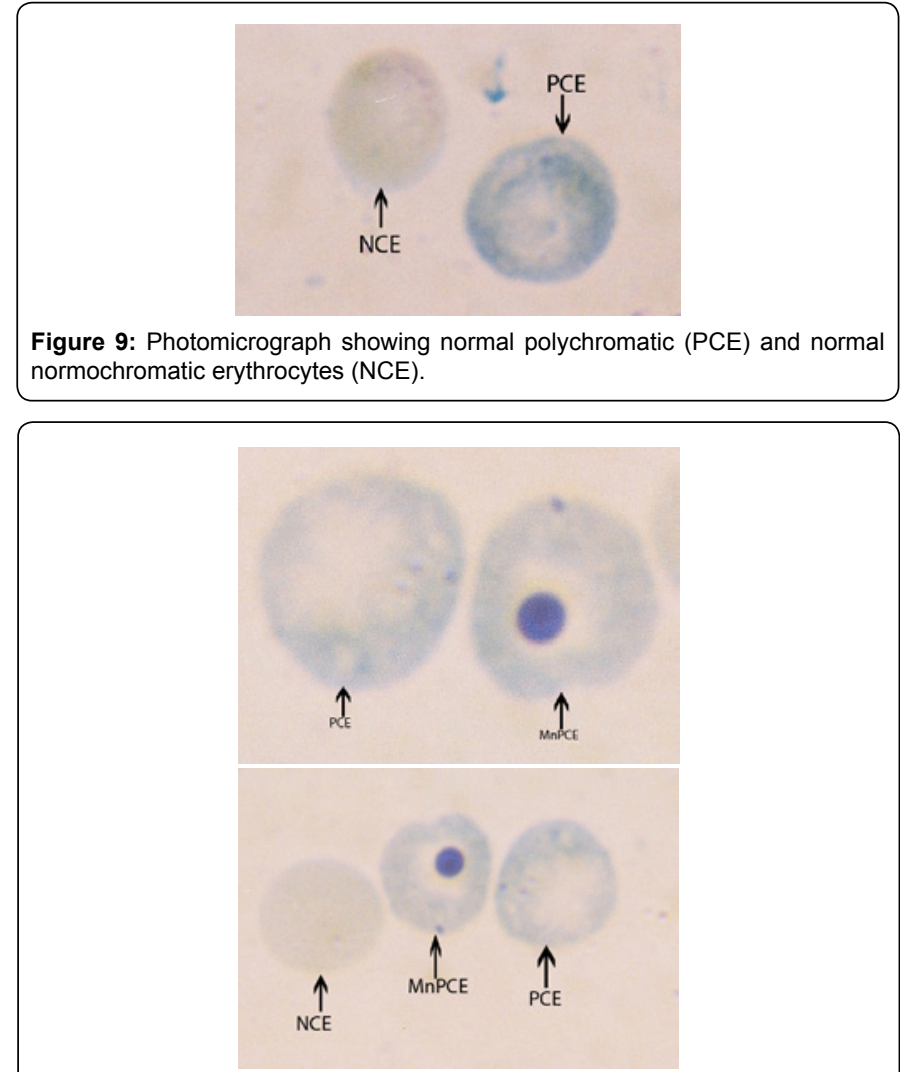

Figure 10: Photomicrograph showing normal polychromatic (PCE) and micronucleated polychromatic erythrocytes (MnPCE).

cells in the lumen. (Figure 5) and thickened, hyalinizied wall of arterioles were occasionally observed in the widened intertubular regions with eosinophilic deposition (Figure 6) at the third week of nicotine treatment.

At fourth week, sections of the testis from male Swiss albino mice treated with nicotine for four weeks showed scattered apoptotic cells at the lumen portion of many seminiferous tubules (Figure 7). Many seminiferous tubules showed nuclear vacuolation (Figure 8) together with large apoptotic cells were seen between layers (Figure 9). Widened interstial areas with marked reduction in interstial Leydig cells (Figure 10a \& 10b).

Histological examination of sections in the testis of male Swiss albino mice treated with nicotine and green tea extract for four successive weeks revealed different degrees of amelioration in response to the time of treatment and compared to the intervals of nicotine group. Mild reduction in germ layers and sperm appeared in focal seminiferous tubules. Scattered seminiferous tubules had exfoliated germ cells in the lumen (Figure 11) and Interstial Leydig cells showed mild increased compared to the nicotine group at the same interval (Figure 12). At the last week of treatment, mild reduction in sperm occasional seen in few seminiferous tubules (Figure 13). Interstial spaces were within normal limit and Leydig cells approached normal appearance and distribution compared to the nicotine at the same interval (Figure 13).

\section{Histomorphometrical studies}

The histomorphometrical changes induced by intraperitoneal injection of nicotine at $(1 / 5 \mathrm{LD} 50=2.5 \mathrm{mg} / \mathrm{kg}$ to mice) as well as the protective effects of green tea at $(40 \mathrm{mg} / \mathrm{kg}$.b.w.) for one, two, three 


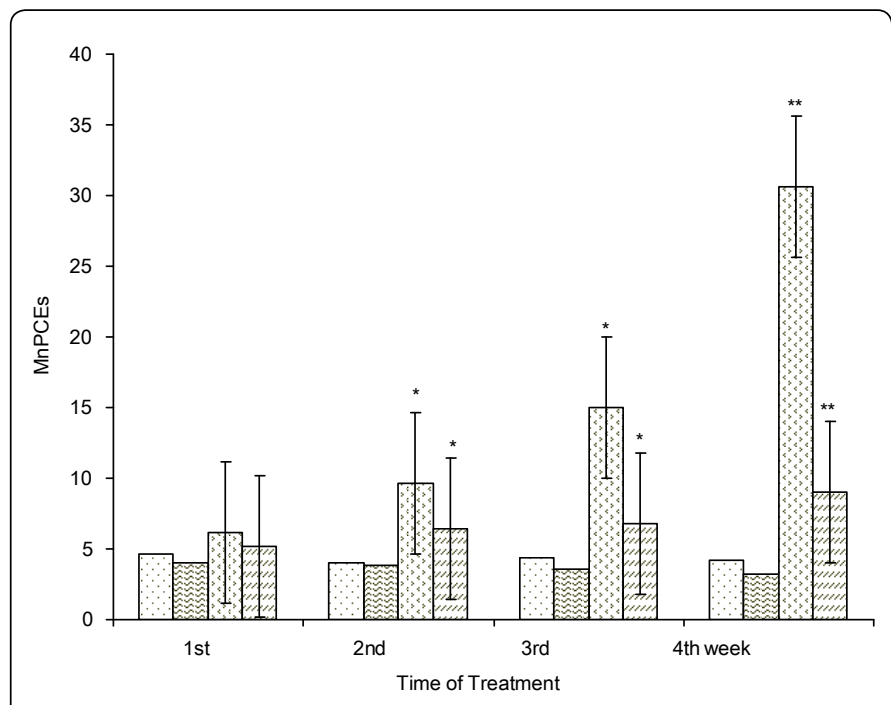

$\square$ Control $\square$ Green tea extract $\square$ Nicotine $\square$ Nicotine+Green tea extract

In each group, twenty animals were used, five animal for each studied week. Data are represented as mean. $(P<0.05)$ is significant $\left(^{*}\right)$ and $(P<0.01)$ is highly significant $\left({ }^{* *}\right)$ : Comparison takes place between control and nicotine group and /or between nicotine group and nicotine-green tea extract group.

Figure 11: The mean number of micronucleated polychromatic erythrocytes in nicotine and nicotine-green tea extract groups in male Swiss albino mice.

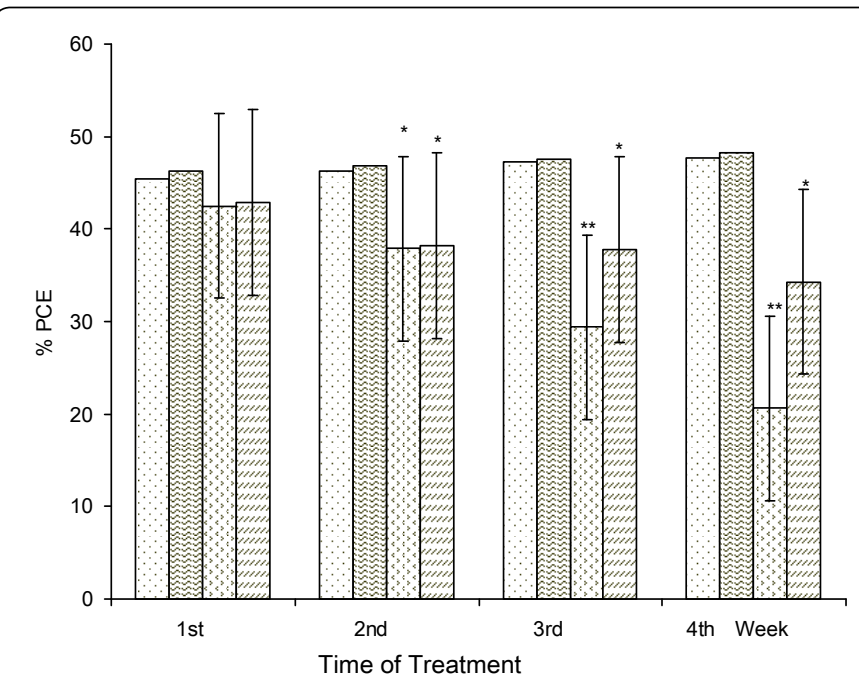

$\square$ Control $\square$ Green tea extract $\square$ Nicotine $\square$ Nicotine + Green tea extract

In each group, twenty animals were used, five animal for each studied week. Data are represented as mean. $(P<0.05)$ is significant $\left(^{*}\right)$ and $(P<0.01)$ is highly significant $\left(^{* *}\right)$ : Comparison takes place between control and nicotine group and /or between nicotine group and nicotine-green tea extract group.

Figure 12: The mean percentage of polychromatic erythrocytes in nicotine and nicotine-green tea extract group in male Swiss albino mice.

and four weeks with or without nicotine were investigated in the testis of male mice using image analysis. Numbers of Leydig cells in testis were shown in (Table 2).

It could be concluded that the number of Leydig cells in testis section throughout all intervals of green tea extract administered was within the accepted spontaneous range for control.
The nicotine treatment for one week induced insignificant decrease in the numbers of Leydig cells (18.10 \pm 2.28$)$ compared to the control group $(23.40 \pm 1.78)$. A significant decreased in the number of Leydig cells was induced when nicotine treatment took place for two weeks compared to the control group $(23.70 \pm 1.72)(\mathrm{P}<0.05)$. Animals received nicotine for three and four weeks, exhibited also a highly significant decrease in the number of Leydig cells $(12.4 \pm 1.97$ and $9.5 \pm 1.46$, respectively) when compared control group (23.90 \pm 1.94 and $24.60 \pm 2.24),(P<0.01)$.

Treatment with green tea extract prevented the decrease in the numbers of Leydig cells observed in the nicotine treated male Swiss albino mice, with different degrees. It showed also a general increase in these cells with increase periods of administration. When treatment with nicotine and green tea extracts took place for one and two weeks $(21.30 \pm 1.88$ and $19.70 \pm 2.29)$ an insignificant increase in the number of Leydig cells was detected in comparison with the nicotine treatment at same intervals $(18.10 \pm 2.28$ and $15.30 \pm 1.78$, respectively) or control group $(23.40 \pm 1.78)$. While nicotine and green tea extract treatment for three weeks $(19.50 \pm 2.59)$ caused a significant increased in the number of Leydig cells and a highly significant increase for four weeks $(21.60 \pm 2.39)$ of treatment in compared to the three and four weeks of the nicotine treatment

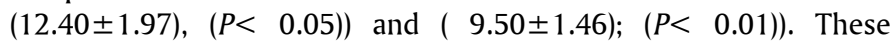
increases $(21.60 \pm 2.39)$ come up to the same range of control value, but still insignificantly lower to the control $(24.60 \pm 2.24)$.

As depicted in (Figure 13), the numbers of Leydig cells were significantly reduced in the nicotine treated groups, while the treatment with nicotine and green tea extract significantly increase their numbers compared to the control groups.

\section{Cytogenetical studies}

The cytogenetic damage induced by intraperitoneal injection of nicotine at $(1 / 5 \mathrm{LD} 50=2.5 \mathrm{mg} / \mathrm{kg}$ to mice) as well as the anti-

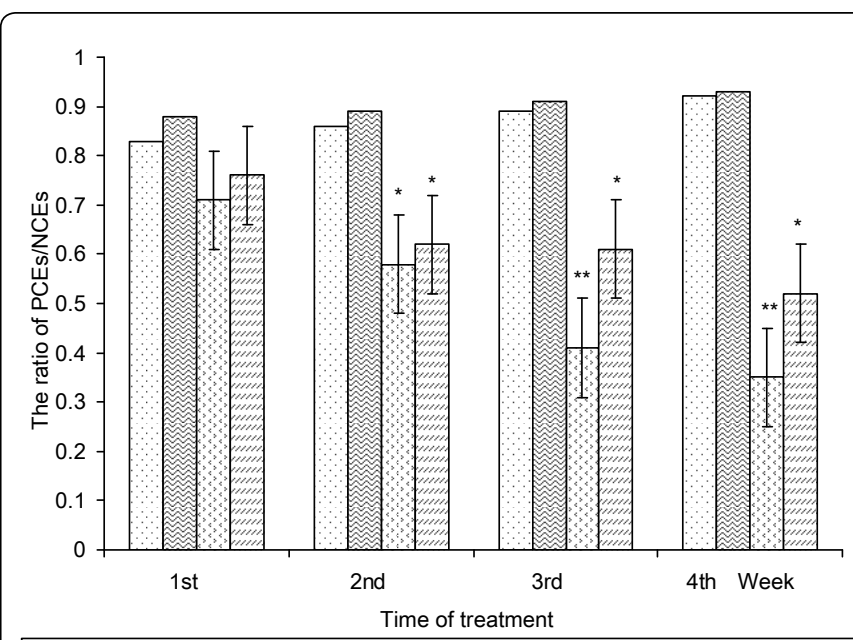

$\square$ Control $\quad$ G Green tea extract $\square$ Nicotine $\square$ Nicotine + Green tea extract

In each group, twenty animals were used, five animal for each studied week. Data are represented as mean. $(P<0.05)$ is significant $\left(^{*}\right)$ and $(P<0.01)$ is highly significant $\left({ }^{* *}\right)$ : Comparison takes p pace group and /or between nicotine group and nicotine-green tea extract group.

Figure 13: The ratio of mean percentage of polychromatic to normochromatic erythrocytes in nicotine and nicotine-green tea extract group in male Swiss albino mice. 
TOTAL NO. OF MnPCE / 5000 PCE

\begin{tabular}{|c|c|c|c|c|}
\hline Nicotine -Green Tea Extract Groups & $\begin{array}{l}\text { Nicotine } \\
\text { groups }\end{array}$ & Green Tea Groups & $\begin{array}{l}\text { Control } \\
\text { Groups }\end{array}$ & 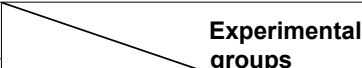 \\
\hline (Mean \pm S.E.) & (Mean \pm S.E.) & (Mean \pm S.E.) & (Mean \pm S.E.) & $\begin{array}{l}\text { Time of } \\
\text { Treatment }\end{array}$ \\
\hline \begin{tabular}{|l|}
$\mathbf{2 6}$ \\
$5.20 \pm 0.66^{\mathrm{Ab}}$ \\
$\mathbf{3 2}$ \\
$6.40 \pm 1.21^{\mathrm{Bba}}$ \\
$\mathbf{3 4}$ \\
$6.80 \pm 0.66^{\mathrm{Bba}}$ \\
$\mathbf{4 5}$ \\
$9.00 \pm 1.14^{\mathrm{Ba}}$
\end{tabular} & $\begin{array}{l}\mathbf{3 1} \\
6.20 \pm 0.86^{\mathrm{Ac}} \\
\mathbf{4 8} \\
9.60 \pm 1.166^{\mathrm{Acb}} \\
\mathbf{7 5} \\
15.00 \pm 1.22^{\mathrm{Ab}} \\
153 \\
30.60 \pm 4.52^{\mathrm{Aa}}\end{array}$ & $\begin{array}{l}20 \\
4.00 \pm 0.71^{\mathrm{Aa}} \\
19 \\
3.80 \pm 0.86^{\mathrm{Ba}} \\
18 \\
3.60 \pm 0.51^{\mathrm{Ca}} \\
16 \\
3.20 \pm 0.58^{\mathrm{Ba}}\end{array}$ & $\begin{array}{l}23 \\
4.60 \pm 0.75^{\mathrm{Aa}} \\
20 \\
4.00 \pm 0.84^{\mathrm{Ba}} \\
22 \\
4.40 \pm 0.68^{\mathrm{CBa}} \\
21 \\
4.20 \pm 0.58^{\mathrm{Ba}}\end{array}$ & $\begin{array}{l}\text { Week } 1 \\
\text { Week } 2 \\
\text { Week } 3 \\
\text { Week } 4\end{array}$ \\
\hline
\end{tabular}

$9.00 \pm 1.14^{\mathrm{Ba}}$

$30.60 \pm 4.52^{\mathrm{A}}$

$3.20 \pm 0.58^{\mathrm{Ba}}$

$4.20 \pm 0.58^{\mathrm{B}}$

Week 4

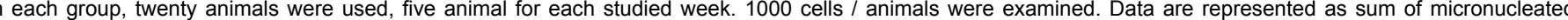
polychromatic erythrocytes and mean \pm stander errors of 5 counting values in each studied week of treatment for each group. Capital letters represent comparison between different group and Small letters represent comparison between different weeks within each group. $(P<0.05)$ is significant and $(P<0.01)$ is highly significant. MnPCEs = It equaled to number of Micronucleated Polychromatic Erythrocytes in 1000 Polychromatic Erythrocytes.

Table 1: The effect of nicotine, green tea extract and nicotine with green tea extract treatment on the mean number of micronucleated polychromatic erythrocytes in male Swiss albino mice.

\begin{tabular}{|c|c|c|c|c|c|}
\hline $\begin{array}{l}\text { Nicotine -Green Tea } \\
\text { groups }\end{array}$ & \begin{tabular}{|l|} 
Nicotine \\
groups
\end{tabular} & Green Tea groups & $\begin{array}{l}\text { Control } \\
\text { groups }\end{array}$ & $\begin{array}{l}\text { Groups of } \\
\text { Experimental }\end{array}$ & \\
\hline (Mean \pm S.E.) & (Mean \pm S.E.) & (Mean \pm S.E.) & (Mean \pm S.E.) & $\begin{array}{l}\text { Of } \\
\text { Treatment }\end{array}$ & Parameter \\
\hline $42.96 \pm 2.26^{\mathrm{Aa}}$ & $42.50 \pm 1.58^{\mathrm{Aa}}$ & $46.30 \pm 1.02^{\mathrm{Aa}}$ & $45.40 \pm 0.95^{\mathrm{Aa}}$ & Week 1 & \\
\hline $38.18 \pm 0.85^{\text {Bba }}$ & $37.94 \pm 0.62^{\mathrm{Ba}}$ & $46.90 \pm 1.49 \mathrm{Aa}$ & $46.34 \pm 0.66^{\mathrm{Aa}}$ & Week 2 & \\
\hline $37.84 \pm 0.79^{\text {ваa }}$ & $29.38 \pm 3.92^{\mathrm{cb}}$ & $47.60 \pm 0.64 \mathrm{Aa}$ & $47.28 \pm 0.43^{\mathrm{Aa}}$ & Week 3 & $\%$ PCE \\
\hline $34.32 \pm 1.17^{\mathrm{Bb}}$ & $20.60 \pm 2.45^{\mathrm{cc}}$ & $48.26 \pm 0.48^{\mathrm{Aa}}$ & $47.70 \pm 0.75^{\mathrm{Aa}}$ & Week 4 & \\
\hline $57.04 \pm 2.26^{\mathrm{Ab}}$ & $57.50 \pm 1.58^{\mathrm{AC}}$ & $53.70 \pm 1.02^{\mathrm{Aa}}$ & $54.60 \pm 0.95^{\mathrm{Aa}}$ & Week 1 & \\
\hline $61.82 \pm 0.85^{\mathrm{Aab}}$ & $62.06 \pm 0.62^{\mathrm{Ac}}$ & $53.10 \pm 1.49^{\mathrm{Ba}}$ & $53.66 \pm 0.66^{\mathrm{Ba}}$ & Week 2 & \\
\hline $62.16 \pm 0.79^{\text {Bab }}$ & $70.62 \pm 3.92^{\mathrm{Ab}}$ & $52.40 \pm 0.64 \mathrm{Ca}$ & $52.72 \pm 0.43^{\mathrm{Ca}}$ & Week 3 & $\%$ NCE \\
\hline $65.68 \pm 1.17^{\mathrm{Ba}}$ & $79.40 \pm 2.45^{\mathrm{Aa}}$ & $51.74 \pm 0.48^{\mathrm{Ca}}$ & $52.30 \pm 0.75^{\mathrm{Ca}}$ & Week 4 & \\
\hline $0.76 \pm 0.06^{\mathrm{Aa}}$ & $0.71 \pm 0.04^{\mathrm{Aa}}$ & $0.88 \pm 0.04^{\mathrm{Aa}}$ & $0.83 \pm 0.03^{\mathrm{Ab}}$ & Week 1 & \\
\hline $0.62 \pm 0.02^{\text {Bab }}$ & $0.58 \pm 0.02^{\mathrm{Ba}}$ & $0.89 \pm 0.05^{\text {Aa }}$ & $0.86 \pm 0.02^{\text {Aba }}$ & Week 2 & \%DCF INCEO \\
\hline $0.61 \pm 0.20^{\mathrm{Bab}}$ & $0.41 \pm 0.08^{\mathrm{cb}}$ & $0.91 \pm 0.02^{\mathrm{Aa}}$ & $0.89 \pm 0.01^{\mathrm{Aba}}$ & Week 3 & \%PCE / NCE\% \\
\hline $0.52 \pm 0.02^{\mathrm{Bb}}$ & $0.35 \pm 0.09^{\mathrm{cc}}$ & $0.93 \pm 0.02^{\mathrm{Aa}}$ & $0.92 \pm 0.02^{\mathrm{Aa}}$ & Week 4 & \\
\hline
\end{tabular}

In each group, twenty animals were used, five animal for each studied week. 1000 cells / animals were examined. Data are represented as mean \pm stander errors of 5 counting values in each studied week of treatment for each group. Capital letters represent comparison between different group and Small letters represent comparison between different weeks within each group. $(P<0.05)$ is significant and $(P<0.01)$ is highly significant. \%PCE $=[\mathrm{PCE} /(\mathrm{PCE}+\mathrm{NCE})] \times 100$., \%NCE $=[\mathrm{NCE} /(\mathrm{NCE}+$ $\mathrm{PCE})] \times 100$.

Table 2: The effect of nicotine, green tea extract and nicotine with green tea extract treatment on the mean percentage of polychromatic erythrocytes and the ratio of mean percentage of polychromatic to normochromatic erythrocytes in male Swiss albino mice.

mutagenic effects of green tea extract at $(40 \mathrm{mg} / \mathrm{kg}$.b.w.) treated also intraperitoneally for one, two, three and four weeks with or without nicotine were investigated in the bone marrow of male Swiss albino mice utilizing the micronucleus assay. The frequencies of micronucleated polychromatic erythrocytes (MnPCE) numbers in each treatment group as well as the PCE / NCE ratio are shown in Table 1 and Table 2. The normal polychromatic erythrocytes (PCE), normal normochromatic erythrocytes (NCE) and micronucleated polychromatic erythrocytes (MnPCE) showing in (Figure 13).

Nicotine treatment induced an insignificant increase in the mean number of MnPCEs after one week $(6.20 \pm 0.89)$ compared to the control group (4.6 \pm 0.74$)$. For two and three weeks of treatment a significant increase mean number of MnPCEs $(9.60 \pm 1.166$ and 15.00 \pm 1.224 respectively), $(P<0.05)$ were obtained when compared to the control values $(4.00 \pm 0.84$ and $4.40 \pm 0.68)$ at same intervals of treatment, while a highly significant increase was observed following the treatment with the nicotine for four weeks $(30.60 \pm 4.523),(P$ $<0.01)$ when compared to control values $(4.20 \pm 0.58)$ at same intervals of treatment. Nicotine treatment for four weeks $(30.60 \pm$ 4.523), $(P<0.01)$ caused a highly significant increase compared to one, two and three week of nicotine treatment $(6.20 \pm 0.89 ; 9.6 \pm$ 1.16 and $15.00 \pm 1.224$, respectively).

The treatment of nicotine and green tea extract to the animals was effective in reducing the mean number of MnPCEs with the time of treatment. As depicted in (Figure 13), the mean number of MnPCEs was significantly increased in nicotine treated groups and treatment with nicotine and green tea extract significantly reduced the mean number of MnPCEs compared to control group.

(Table 2) summarizes the results of bone marrow cytotoxicity related to the treatment with nicotine and / or green tea extract. The statistical analysis of the data is also provided. The treatment with green tea extract for one, two, and three and even for four weeks did not induced evident bone marrow cytotoxicity in comparison to the control group.

Nicotine treated male Swiss albino mice, for one, two, three and four weeks resulted in highly significant alterations of all monitored parameters (\%PCEs, \%NCEs \& \%PCEs / \%NCEs), but with different intensity and distinctive time trends. When compared to the control group (45.40 \pm 0.953$)$.

Animals that treated with nicotine and green tea extract, for three and four weeks induced a significant increase of the mean percentage of PCEs and the ratio of mean percentage of PCEs to NCEs when compared to the three and four weeks of nicotine treated group.

\section{Discussion}

\section{Histological studies}

In the present study, the histological examination of testis sections taken in the male Swiss albino mice treated with nicotine for one and two weeks showed mild to moderate reduction in spermatogenic 
series and reduction in sperm count in some seminiferous tubules. This was accompanied with scattered nuclear pyknotic change in the basal cell layers observed in first week of treatment. Prominent degenerative changes were also noticed in few seminiferous tubules after the second week.

This was in agreement with the work done by [12] stated that administration of different doses of nicotine reduces the weight of the testis, and the number of spermatocytes and spermatids and Sertoli cells accompanied with thickening of the tunica propria with a daily treatment with nicotine. Elshal et al. [13], reported that cigarette smoking was associated with immature spermatozoa, sperm head defect and disturbances in spermatozoa chromatin and DNA integrities in idiopathic infertile subject. Kapawa et al. [7], also revealed that cigarette smoke-exposure impaired epididymal sperm maturation process and diminished capacity of spermatozoa to penetrate oocytes. The structural changes observed in the seminiferous tubules of the current study could be explained by the work done by Ahmadnia et al. [31] who attributed these changes to the vascular insufficiency resulting from nicotine toxicity. Aydos attributed the damage in testicular tissue to the direct cytotoxic effects of nicotine on spermatogenic cells or via inhibition of prostaglandin's synthesis, that play a functional role in the reproduction system of the male mice and mainly initiating and completing spermatogenesis and steroidgenesis in the testis. Reddy et al. [12] revealed that nicotine is central nervous system depressors that can inhibit the neural stimulus essential for the release of pituitary gonadotrophins.

In the present study the combined treatment of nicotine and green tea extract ameliorated the histological changes in testicular tissue induced by nicotine alone. This was evidenced by normal appearance of spermatogenic layers and sperm in the seminiferous tubules. The interstial spaces and Leydig cells appeared also in normal shape. Hafez et al. [25], found that oral pretreatment of rats; with green tea at a dose $1.7 \%$ to the exposure to radiation exerted a noticeable amelioration in the structure of kidney, testes, spleen, and heart.

Sriram et al. [26] revealed also that EGCG at a dose of $20 \mathrm{mg}$ / $\mathrm{kg}$ body weight significantly improved the body weight, enzymic and non enzymic antioxidants and considerably decreased the lipid peroxidation marker levels. The ameliorating effect of green tea extract in the present study may be attributed to its antioxidant properties [32]. In conclusion, the present studies indicating the efficiency of green tea extract to restore the original appearance of testicular tissue.

\section{Histomorphometrical studies}

In the present study, the histomorphometrical examination of testis tissue of animals treated with nicotine revealed gradually significant decrease in mean number of interstial Leydig cells in testicular tissue throughout the experimental weeks compared to the control level.

The observed reduction in Leydig cells in testis section of male Swiss albino mice in the present study may be attributed to several features of apoptosis exhibited by nicotine [11]. Cohen et al. [33] suggested that nicotine activated specific intracellular death-related pathways. In addition, nicotine enhanced the expression of the activated form of caspase- 3 and caspase- 3 enzyme activity (one of the key executors of apoptosis, which is responsible either partially or wholly for the proteolytic cleavage of many proteins) [34].

In the present work, histomorphometrical measuring of
Leydig cells in animals treated with green tea extract treatment and nicotine recorded that mean number of interstial Leydig cells returned gradually to normal. In the present study, the ameliorated effect of green tea extract on mean number of Leydig cells due to its antioxidant activity [35], free radical scavenge properties [36,37]. It suppresses ROS formation through its polyphenolic contents such as catechins imparting astrong antioxidant activity.

In conclusion, green tea extract could reduce the nicotine toxicity and caused amelioration in the number of Leydig cells in testis of male Swiss albino mice.

Cytogenetically studies: The Present study evaluated that, nicotine is clastogenic in the mean number of micronucleated polychromatic erythrocytes (MnPCEs) and ratio of mean percentage of polychromatic to normochromatic erythrocytes (PCEs/ NCEs).It caused gradually and highly significant increase in the mean number of MnPCEs; however caused significant decrease in ratio of mean percentage of PCEs/ NCEs compared to control. The micronucleus technique has been proposed as a useful tool for measurement of genotoxicity [29].

Our findings are consistent with Bandyopadhyaya et al. [38]; Argentin and Cicchetti [39]; Arabi [40] who stated that nicotine, the well known addictive chemical of tobacco and active medication for several diseases and is a potential genotoxic compound. In the present study, genotoxicity properties of nicotine may be attributed to excess production of two highly mutagenic nitrosamine, $N$ '-nitrosonor nicotine (NNN) and 4-(methylnitrosamine)-1-(3-pyridyl)-1- butanone (NNK) which product from nicotine during tobacco curing or burning $[41,42,43]$. Also, in the present study, genotoxicity of nicotine also may be attributed to excess production of malondialdehyde (MDA), is end product of lipid peroxidation as recorded by Sheng et al. [44]; Sudheer et al. [45].

In the present study, the treatment with nicotine and green tea extract caused also an improvement in the ratio of mean percentage of PCEs/NCEs and a significant decrease in the increase of the mean number of MnPCEs induced by nicotine toxicity alone. This result is in agreement with Fujii et al. $[46,47]$ that, demonstrating that green tea did not pose toxic nor adverse events. Ogura et al. [48], also demonstrated no significant increase in micronucleated polychromatic erythrocytes (MNPCEs) in the bone marrow.

Another reason for the beneficial effect of green tea extract on genotoxicity of nicotine can be attributed to the antioxidant properties and ROS scavenge properties $[49,37,32]$ and antimutugenicity activity [50,51] of green tea extract [42]. In conclusion, the results of the present study showed that green tea extract act as protective against genotoxicity of nicotine due its antimutugenicity activity and antioxidant properties.

\section{References}

1. El-Sokkary GH, Cuzzocrea S, Reiter RJ (2007) Effect of chronic nicotine administration on the rat lung and liver: Beneficial role of melatonin. Toxicology 239: 60-67.

2. Hecht SS (2003) Tobacco carcinogens, their biomarkers and tobacco-induced cancer. Nat Rev Cancer 3: 733-744.

3. Yildiz D (2004) Nicotine it's metabolism and an overview of its biological effects Toxicon 43: 619-632

4. Dajas-Bailador F, Wonnacott S (2004) Nicotinic acetylcholine receptors and the regulation of neuronal signaling. Pharmacol Sci 25: 317-324

5. Gossain VV, Sherma NK, Srivastava L, Michelakis AM, Rovner DR (1986) Hormonal effects of smoking. II. Effects on plasma cortisol, growth hormone and prolactin. Am J Med Sci 291: 325-327. 
Citation: Gawish AM, Ramadan S, Hassan AM, Issa AM (2010) Morphometrical, Histopathological, and Cytogenetical Ameliorating Effects of Green Tea Extract on Nicotine Toxicity of the Testis of Rats. J Cytol Histol 1:105. doi:10.4172/2157-7099.1000105

6. Patterson TR, Stringham JD, Meikle AW (1990) Nicotine and cotinine inhibit steroidogenesis in mouse Leydig cells. Life Sci 46: 265-272.

7. Kapawa A, Giannakis D, Tsoukanelis K, Kanakas N, Baltogiannis D, et al. (2004) Effect of paternal cigareete smoking on testicular function, sperm fertilizing capacity, embryonic development, and blastocytst capacity for implantation in rats. Andrologia 36: 57-68.

8. Polyzos A, Schmid TE, Piña-Guzmán B, Quintanilla-Vega B, Marchetti $F$ (2009) Differential sensitivity of male germ cells to mainstream and sidestream tobacco smoke in the mouse. Toxicol Appl Pharmacol 237: 298-305.

9. Yauk CL, Berndt ML, Williams A, Rowan-Carroll A, Douglas GR, et al. (2007) Mainstream tobacco smoke causes paternal germ-line DNA mutation. Cancer Res 67: 5103-5106.

10. Yamamoto $Y$, Isoyama E, Sofikitis N, Miyagawa I (1998) Effect of smoking on testicular function and fertilizing potential in rats. Urol Res 26: 45-48.

11. Kim KH, Joo KJ, Park HJ, Kwon $\mathrm{CH}$, Jang MH, et al. (2005) Nicotine induces apoptosis in TM3 mouse Leydig Cells. Fertil Steril 83: 1093-1099.

12. Reddy S, Londonkar R, Ravindra, Reddy S, Patil SB (1998) Testicular changes due to graded doses of nicotine in albino mice. Indian J Physiol Pharmacol 42: 276-280.

13. Elshal MF, El-Sayed IH, Elsaied MA, El-Masry SA, Kumosani TA (2009) Sperm head defects and disturbances in spermatozoal chromatin and DNA integrities in idiopathic infertile subjects: Association with cigarette smoking. Clin Biochem 42: $589-594$

14. Sergerie M, Ouhilal S, Bissonnette F, Brodeur J, Bleau G (2000) Lack of association between smoking and DNA fragmentation in the spermatozoa of normal men. Hum Reprod 15: 1314-1321.

15. Potts RJ, Newbury CJ, Smith G, Notarianni LJ, Jefferies TM (1999) Sperm chromatin damage associated with male smoking. Mutat Res 423: 103-111.

16. Horak S, Polanska J, Widlak P (2003) Bulky DNA adducts in human sperm: relationship with fertility, semen quality, smoking, and environmental factors. Mutat Res 537: 53-65.

17. Robbins WA, Vine MF, Truong KY, Everson RB (1997) Use of fluorescence in situ hybridization (FISH) to assess effects of smoking, caffeine, and alcohol on aneuploidy load in sperm of healthy men. Environ Mol Mutagen 30: 175-183.

18. Rubes J, Lowe X, Moore D 2nd, Perreault S, Slott V, et al. (1998) Smoking cigarettes is associated with increased sperm disomy in teenage men. Fertil Steril 70: 715-723.

19. Doolittle DJ, Winegar R, Lee CK, Caldwell WS, Hayes AW, et al. (1995) The genotoxic potential of nicotine and its major metabolites. Mutat Res 344: 95102.

20. Trivedi AH, Dave BJ, Adhvaryu SG (1990) Assessment of genotoxicity of nicotine employing in vitro mammalian test systems. Cancer Lett 54: 89-94.

21. Sen S, Sharma A (1991) Inhibition of clastogenic effects of nicotine by chrorophyllin in mice bone marrow cells in vivo Phytother Res 6: 130-133.

22. Lee IP, Kim YH, Kang MH, Roberts C, Shim JS, et al. (1997) Chemopreventive effect of green tea (Camellia sinensis) against cigarette smokeinduced mutations (SCE) in humans. J Cell Biochem Suppl 27: 68-75.

23. Therriault MJ, Proulx LI, Castonguay A, Bissonnette EY (2003) Immunomodulatory effects of the tobacco-specific carcinogen, NNK, on alveolar macrophages. Clin Exp Immunol 132: 232-238.

24. Reibel J (2003) Tobacco and oral diseases. Update on the evidence, with recommendations. Med Princ Pract 11: 22-32.

25. Hafez SE (2006) Using green tea in controlling structural disorders of radiation in some organs in male albino rats. J Drug Res 27: 90-97.

26. Sriram N, Kalayarasan S, Sudhandiran G (2008) Enhancement of Antioxidant Defense System by Epigallocatechin-3- gallate during Bleomycin Induced Experimental Pulmonary Fibrosis. Biol Pharm Bull 31: 1306-1311.

27. Di Paola R, Mazzon E, Muià C, Genovese T, Menegazzi M, (2005) Green tea polyphenol extract attenuates lung injury in experimental model of carrageenan induced pleurisy in mice. Respir Res 6: 66

28. Bancroft J, Gamble M (2002) "Theory and Practice of Histological Techniques." 5th (Ed.) Churchil Livingstone, London.

29. Krishna G, Hayashi M (2000) In vivo rodent micronucleus assay: protocol, conduct and data interpretation. Mutat Res 455: 1550-166.

30. Cole RJ, Taylor N, Cole J, Arlett CF (1981) Short term testis for transplacentally active carcinogens, I. Micronucleus formation in fetal and maternal mouse erythroblasts. Mutat Res 80: 141-157.

31. Ahmadnia H, Ghanbari M, Moradi MR, Khaje-Dalouee M (2007) Effect of Cigarette Smoke on Spermatogenesis in Rats. Urol J 4: 159-163.

32. Patra SK, Rizzi F, Silva A, Rugina DO, Bettuzzi S (2008) Molecular targets of $(-)$ - Epigallocatechin-3-gallate (EGCG): Specificity and interaction with memberane lipid rafts. J Physiol Pharmacol 59: 217-235.

33. Cohen GM (1997) Caspases: the executioners of apoptosis. Biochem J 326 1-16.

34. Nagata S (1997) Apoptosis by death factor. Cell 88: 355- 365

35. Hakim IA, Harris RB, Brown S, Chow HH, Wiseman S, et al. (2003) Effect of increased tea consumption on oxidative DNA damage among smokers: a randomized controlled study. J Nutr 133: 3303S-3309S.

36. Yoko S, Santosh K (2005) Factors affecting the levels of catechines and caffeine in tea beverage: estimated dailly intakes and antioxidant activity. J Sc Food Agric 85: 2125-2133.

37. Coyle CH, Philips BJ, Morrisroe SN, Chancellor MB, Yoshimura N (2008) Antioxidant effects of green tea and its polyphenols on bladder cells. Life Sci 83: $12-18$.

38. Bandyopadhyaya G, Sinha S, Chattopadhyay BD, Chakraborty A (2008) Protective role of curcumin against nicotine-induced genotoxicity on rat liver under restricted dietary protein. Europ J Pharmacol 588: 151-157.

39. Argentin G, Cicchetti R (2004) Genotoxic and antiapoptotic effect of nicotine on human gingival fibroblasts. Toxicol Sci 79: 750-81.

40. Arabi M (2004) Nicotinic infertility: assessing DNA and plasma membrane integrity of human spermatozoa. Andrologia 36: 305-310.

41. Campain JA (2004) Nicotine: potentially a multifunctional carcinogen? Toxico Sci 79: 1-3.

42. Neogy S, Das S, Mahapatra SK, Mandal N, Roy S (2008) Amelioratory effect of Andrographis paniculata Nees on liver, kidney, heart, lung and spleen during nicotine induced oxidative stress. Environmental Toxicol Pharmacol 25: 321 328 .

43. Benowitz N, Goniewicz ML, Eisner MD, Lazcano-Ponce E, Zielinska-Danch W, et al. (2010) Urine cotinine underestimates exposure to tobacco-derived lung carcinogen 4-(methylnitrosamino)-1-(3-pyridyl)-1-butanone (NNK) in passive compared to active smokers. Cancer Epidemiol Biomarkers Prev 19: 27952800.

44. Sheng HP, Yuen ST, So HL, Cho CH (2001) Hepatotoxicity of Prenatal and Postnata Exposure to Nicotine in Rat Pups. Exp Biol Med (Maywood) 226 934-939.

45. Sudheer AR, Muthukumaran S, Kalpana C, Srinivasan M, Menon VP (2007) Protective effect of ferulic acid on nicotine-induced DNA damage and cellular changes in cultured rat peripheral blood lymphocytes: A comparison with $\mathrm{N}$-acetylcysteine. Toxicol in vitro 21: 576-585.

46. Fujii H, Nakagawa T, Nishioka H, Sato E, Hirose A, et al. (2007) Preparation, characterization and anti-oxidative effects of oligomeric proanthocyanidin-Lcysteine complexes. J Agric Food Chem 55: 1525-1531.

47. Fujii H, Sun B, Nishioka H, Hirose A, Aruoma OI (2007) Evaluation of the safety and toxicity of the oligomerized polyphenol Oligonol. Food Chem Toxicol 45 : 378-387.

48. Ogura R, Ikeda N, Yuki K, Morita O, Saigo K, et al. (2008) Genotoxicity studies on green tea catechin. Food Chem Toxicol 46: 2190-2200.

49. Glei M, Pool-Zobel BL (2006) The main catechin of green tea (-)-epigallocatechin-3-gallate (EGCG), reduces bleomycin-induced DNA damagein human leucocytes. Toxicol In vitro 20: 295-300.

50. Sugisawa A, Kimura M, Fenech M, Umegaki K (2004) Anti-genotoxic effects of tea catechins against reactive oxygen species in human lymphoblastoid cells. Mutat Res 559: 97-103

51. Takumi-Kobayashi A, Ogura R, Morita O, Nishiyama N, Kasamatsu T (2008) Involvement of hydrogen peroxide in chromosomal aberrations induced by green tea catechins in vitro and implications for risk assessment. Mutat Res 657: 13-18.

52. Schmid W (1975) The micronucleus test. Mutat Res 31: 9-15.

53. Schmid W (1976) The micronucleus test for cytogenetic analysis. In: Chemical Mutagens: Princibles and Methods for their Detection (Hollaender, A. ed.), Volm 4 Plenum New York 31-53. 